\title{
Elacatinus figaro Sazima, Moura \& Rosa, 1997 (Gobiiformes: Gobiidae): Distribution extension of a Brazilian endangered endemic reef fish with comments on south-western Atlantic Ocean biogeography
}

\author{
Daniel Fernando Almeida ${ }^{1}$, Gabriel Soares Araujo ${ }^{1 *}$, Marcelo R. Britto ${ }^{1}$ and Cláudio Luis Santos Sampaio²
}

\begin{abstract}
Background: A new record for Elacatinus figaro, an endangered Brazilian species, is documented for Pedra do Sal, Piauí coast. We present new data about its distribution, discussing on the limits of the Brazilian Province and commenting on the IUCN criteria for evaluation on threatening status.

Results: Five specimens of E. figaro were collected about $550 \mathrm{~km}$ northward from its previously known boundary, overtaking the expectations around its real distribution as presented in the original description.

Conclusions: Results from E. figaro range expansion and new records of species in Brazilian coast fit the hypothesis presented in Floeter et al. (J Biogeogr 35: 22-47, 2008) of a Brazilian Zoogeographic Province, also assigned by Briggs \& Bowen (J Biogeogr 39: 12-30, 2012) on a review of Marine Zoogeographic Provinces.
\end{abstract}

Keywords: Brazilian Province, Conservation status, Endemism, Zoogeography

\section{Background}

The genus Elacatinus Jordan 1904 has currently 25 valid species (Eschmeyer et al., 2016), all but Elacatinus puncticulatus (Ginsburg, 1938), from eastern Pacific, occurring on western Atlantic (Van Tassell, 2011) and three of which endemic to Brazilian waters. Generally, Elacatinus species are small brightly coloured reef inhabitants that feed mainly on parasites by engaging in cleaning symbiosis with larger fishes and invertebrates (Pezold, 1993; Sazima \& Moura, 2000; Sazima et al., 2000; Sazima et al., 2004), being recently used as models for speciation studies on large versus small geographic scales (Colin, 2003;

\footnotetext{
* Correspondence: gabrielsoaraujo@gmail.com

'Departamento de Vertebrados, Universidade Federal do Rio de Janeiro/ Museu Nacional, Setor de Ictiologia, Quinta da Boa Vista s/n, CEP 20940-040 Rio de Janeiro, RJ, Brazil

Full list of author information is available at the end of the article
}

Palumbi \& Warner, 2003; Warner \& Palumbi, 2003; Taylor \& Hellberg, 2005), and connectivity (Colin, 2010), presenting so high speciation rates that yielded a comparison with Tolkien's Hobbits (Palumbi \& Warner, 2003) due to its low mobility and phylopatric behaviour.

One of the Brazilian species, the Barber Goby Elacatinus figaro Sazima, Moura \& Rosa, 1997 was originally described as occurring in "Brazilian Coast", with its distribution from Paraiba State - northern boundary - to Santa Catarina State - southern boundary (Sazima et al., 1997), but with an addendum to its potential occurrence up to Ceará State.

Briggs (1974, 1995), following previous innuendos (Ekman, 1953), recognized Cabo Frio $\left(22^{\circ} 54^{\prime} \mathrm{S}\right)$ as the southern limit of both the Brazilian Province and western Atlantic Tropics, followed by several other authors (Vermeij, 1978; Absalão, 1989; Boschi, 2000; 
Di Dario et al., 2011) with very similar arrangements based on distinct taxonomic groups. On the other hand, Floeter et al. (2008), studying the distribution of a great variety of coastal fish families, recognized an arrangement where the Brazilian Province extends its limits from the mouth of the Amazon River south to Santa Catarina, including the offshore islands of Atol das Rocas, Fernando de Noronha, St Paul's Rocks and Trindade - all of them in Brazilian jurisdictional waters. This arrangement was recently followed by Briggs \& Bowen (2012) in a recent reappraisal of marine biogeographic provinces with particular reference to fish distributions.

Herein, a new record for E. figaro (Fig. 1) is documented for Piauí coast, increasing the knowledge about the species distribution. The Barber Goby, E. figaro, is endangered due to degradation of reef environments and the illegal collection to supply the ornamental marine trade (Gasparini et al., 2005). Herein, we present new data about its distribution, discussing on the limits of the Brazilian Province and conservation status.

\section{Methods}

Field work took place at Pedra do Sal, Piauí State, Brazil $\left(03^{\circ} 32^{\prime} \mathrm{S}, 38^{\circ} 16^{\prime} \mathrm{W}\right)$. Specimens were collected through hand-nets during SCUBA dives, between 2-3 m depth, on March 2015 under license number 10488-1 - from Instituto Brasileiro do Meio Ambiente e dos Recursos Naturais Renováveis (IBAMA) and Instituto Chico Mendes de Conservação da Biodiversidade (ICMBio).

The specimens were fixed in 99,6 GL ethanol. Five vouchers are deposited at Museu Nacional Ichthyological Collection, Rio de Janeiro, Brazil, under catalogue number MNRJ 43599 (Fig. 2).

All major ichthyological collections were examined using speciesLink project (http://www.splink.org.br/index) tools in order to look for $E$. figaro records beyond its original distribution. There, two southern records of $E$. figaro were found for Ceará State, Brazil, collected in 2000 and deposited at Museu de Zoologia da USP, São Paulo, Brazil, under catalogue numbers MZUSP 65161 and MZUSP 65178, but none for Piauí State.

Besides that, to verify the endemicity of the Brazilian Province sensu Floeter et al. (2008), all new marine fish

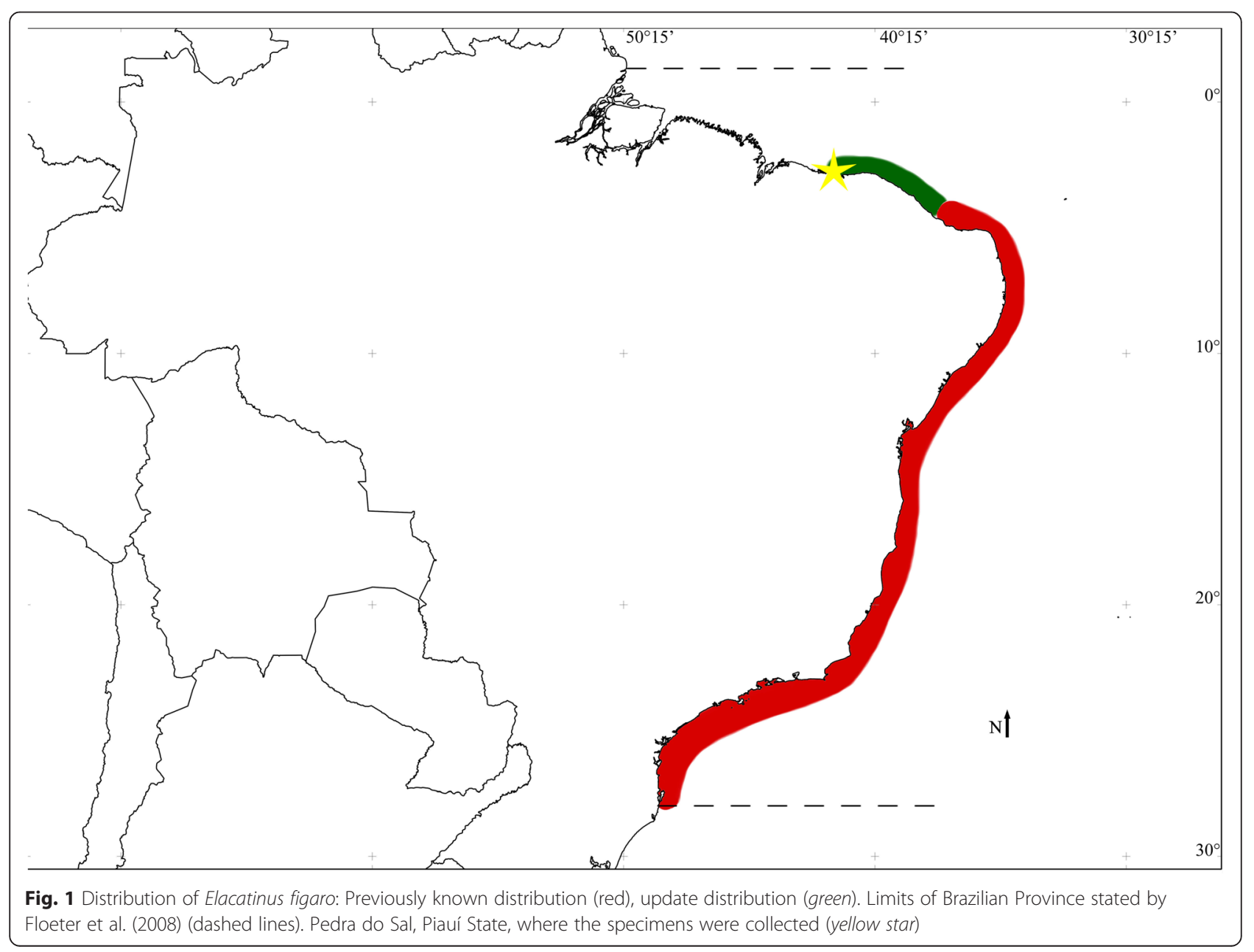




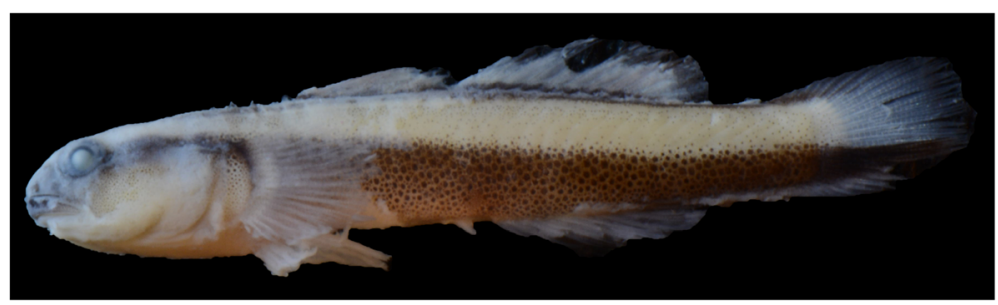

Fig. 2 Elacatinus figaro, MNRJ 43599, 22,8 $\mathrm{mm} \mathrm{SL}$

descriptions and records after 2008 for the speciose families stated by those authors were examined, as well as an extensive literature search on studies discussing on Brazilian Province. Ten new species (Table 1) were found, all of which corroborate Floeter et al. (2008) and Briggs \& Bowen (2012).

Morphological identification was made taking the original description of Elacatinus figaro (Sazima et al., 1997) and Van Tassell (2011) as the base (Fig. 2). Besides, molecular identification was conducted with two markers, a mitochondrial (CytB) and a nuclear (Rho), both reaching a score of $100 \%$ on the blast tool of NCBI GenBank.

\section{Results}

Five specimens of E. figaro were collected about $550 \mathrm{~km}$ northward from its previously known boundary, overtaking the expectations around its real distribution as presented in the original description.

The specimens were collected at a rocky bottom with depths ranging from $0,5 \mathrm{~m}$ to $2,0 \mathrm{~m}$. The visibility was around $0,8 \mathrm{~m}$ due to the proximity of Parnaíba river outfall. Probably as a product of the small input of light, many benthic organisms were not detected on the rocks, but only a very thick layer of green algae.

\section{Discussion}

Despite the radiations in small geographic scales presented by most Caribbean Elacatinus species (Palumbi \& Warner, 2003; Taylor \& Hellberg, 2005), the endemic Brazilian coast E. figaro is the most widespread species of the genus since it occurs throughout most part of its coastal reefs.

As an endemic and endangered species, knowledge of the Barber Goby distribution is essential for conservation purposes (Tyre et al., 2001; Rondinini et al. 2006). The most recent Red List of Brazilian Fauna (Ministério do Meio Ambiente, 2014) lists Elacatinus figaro as a threatened species, and recommends that it fits the Vulnerable (VU) category of IUCN based on A2bcd criteria (population reduction observed, estimated, inferred, or suspected in the past where the causes of reduction may not have ceased, or may not be understood, or may not be reversible, based on (b) an index of abundance appropriate to the taxon, (c) a decline in area of occupancy (AOO), extent of occurrence (EOO) and/or habitat quality, and (d) actual or potential levels of exploitation) (IUCN, 2011). Accordingly, estimates infer that populations of E. figaro decline in nearly $30 \%$ in the last ten years, numbers associated with threats like over capture due to aquarist activity, and large decline of Brazilian coral reefs (ICMBio 2015).

Table 1 Marine species described after 2008 to the speciose families stated by Floeter et al. (2008), and their distribution. Only species occurring in Brazilian waters were included

\begin{tabular}{|c|c|c|}
\hline Family & Species & Distribution \\
\hline \multirow[t]{2}{*}{ Bleniidae } & Scartella itajobi Rangel \& Mendes, 2009 & $\begin{array}{l}\text { Fernando de Noronha Archipelago and São Pedro e São Paulo } \\
\text { Archipelago }\end{array}$ \\
\hline & Hypleurochilus brasil Pinheiro, Gasparini \& Rangel, 2013 & Trindade Island and Martin Vaz Archipelago \\
\hline \multirow[t]{2}{*}{ Gobiidae } & Elacatinus phthirophagus Sazima, Carvalho-Filho \& Sazima, 2008 & Fernando de Noronha Archipelago \\
\hline & Barbulifer enigmaticus Joyeux, Van Tassell \& Macieira, 2009 & From Espírito Santo to São Paulo States \\
\hline \multirow[t]{2}{*}{ Labridae } & Halichoeres rubrovirens Rocha, Pinheiro \& Gasparini, 2010 & Trindade and Martin Vaz Archipelago \\
\hline & Halichoeres sazimai Luiz, Ferreira \& Rocha, 2009 & From Espírito Santo to Santa Catarina States \\
\hline \multirow[t]{2}{*}{ Labrisomidae } & Malacoctenus brunoi Guimarães, Nunan \& Gasparini, 2010 & Trindade and Martin Vaz Archipelago \\
\hline & $\begin{array}{l}\text { Labrisomus conditus Sazima, Carvalho-Filho, Gasparini \& Sazima, } \\
2009\end{array}$ & Fernando de Noronha Archipelago \\
\hline Scaridae & Sparisoma rocha Pinheiro, Gasparini \& Sazima, 2010 & Trindade Archipelago \\
\hline Serranidae & Serranus aliceae Carvalho-Filho \& Ferreira, 2013 & Southeastern Brazil \\
\hline
\end{tabular}


New occurrence records constitute important information that improves evaluation of conservation status. Some of the plausible threats listed to Elacatinus figaro concerns those acting in its geographic range, which also fits at IUCN's "B" criteria (Geographic range in the form of either extent of occurrence and/or area of occupancy). Therefore, we use the georeferenced localities of $E$. figaro from the records available at SpeciesLink plus the new data presented herein in the Geospatial Conservation Assessement Tool (geocat.kew.org) to calculate its extent of occurrence (EOO) and area of occupancy (AOO). Considering a cell width of $2 \mathrm{~km}$, the calculated AOO was $340 \mathrm{~km}^{2}$, which suggests an Endangered (EN) category based on $\mathrm{B} 2$ criteria $\left(\mathrm{AOO}<500 \mathrm{~km}^{2}\right)$. Since $E$. figaro occurs in specific habitats (coral or rocky reefs) in a distributional range with high pressure of human activities, it is possible to detect severe fragmentation of its distribution (IUCN's B(a) criteria), associated with the continuing decline in the quality of its habitat (IUCN's B(b iii) criteria), threats listed by Moura et al. (2008). However, the use of AOO for a taxon as E. figaro seems severely inaccurate, despite of several reef species admittedly display a low occupational range (Taylor \& Hellberg, 2003). Nevertheless, according to Almeida (2011), populations of E. figaro shares haplotypes along larger areas than previously reported for the genera, having haplotypes common to the whole Brazilian northwestern coast and others common to the whole southern/southwestern coast.

The recent range expansion of $E$. figaro, herein recorded, fits within Floeter et al. (2008) and Briggs \& Bowen (2012) arrangement of Brazilian Province (Fig. 1). Except by the Parcel Manuel Luiz, the northernmost coral reef communities in Brazil (Castro \& Pires, 2001), the lack of E. figaro in most of the northern portion of the province, where the reefs are not well developed, is probably due the presence of a barrier between the Parcel and the rest of the Brazilian coastal reef (Rocha \& Rosa, 2001).

It seems that organisms with putative great mobility and cryptical species, that can be easily misidentified by non-specialists, are not the best models for discussing areas of endemism (AoE) as they do not fit classical protocols to establish endemism areas (e.g. Müller, 1973; Linder, 2001). Accordingly, Giokas \& Sfenthourakis (2008) critically discourage the use of widely distributed species for delineation of AoE, stating that they cannot provide enough evidence for it. Morrone (1994) encourages only the use of species with accurately known distributional limits for this purpose.

Some recent uses of fish from these two categories for delimitation of AoE, and hence the Brazilian Province delineation, can be observed. Menni et al. (2010) reviewed chondrichthyan distribution in southwest Atlantic, and besides the great mobility of sharks, skates and rays - that extrapolates the requirements of Müller (1973) and Linder (2001) - authors stated that "disturbances in the southwestern Atlantic may affect large parts of, or even the whole chondrichthyan assemblages", a proposition that by itself points out the group as an unreliable source for $\mathrm{AoE}$ delimitation. On the other side, Odontesthes argentinensis (Valenciennes, 1835) had its northern limit originally established to Santos ( $\left.23^{\circ} 57^{\prime} \mathrm{S}, 46^{\circ} 20^{\prime} \mathrm{W}\right)$. Later, Bemvenuti (2000) proposed Santa Catarina State $\left(28^{\circ} \mathrm{S}\right)$ as its limit, and recently Di Dario et al. (2011) increased it to northern Rio de Janeiro State, based in a large discussion about the limits of Brazilian Province on such boundary. However, subsequently those same authors collected $O$. argentinensis northwards at Marataizes, Espírito Santo state, Brazil (catalogue number NPM 71). This entry not only extrapolates the limits of the provinces under discussion on that paper, but opens for the great probability of a subsequent range expansion of $O$. argentinensis due to misidentification of previously collected material northward Marataizes.

Elacatinus species seem to be good models to study geographic barriers due to its quick speciation and low dispersion (Taylor \& Hellberg, 2005). The genus speciation is sensible to invisible barriers, occurring even though populations reside only within $23 \mathrm{~km}$ of each other in Caribbean waters (Palumbi \& Warner, 2003), therefore E. figaro was the chosen model to discuss onto the limits of Brazilian Province. Furthermore, the requirements of E. figaro, the ten new species descriptions for the Brazilian coast (Table 1), as well as most of the members of the families used by Floeter et al. (2008) are in accordance with Müller (1973) and Linder (2001) protocols to establish AoE.

\section{Conclusions}

Results from E. figaro range expansion and new records of species in Brazilian coast (Table 1) fit the hypothesis of a Brazilian Zoogeographic Province extending from its north portion on the mouth of Amazon River basin to its southern limit at Santa Catarina, Brazil, including its offshore islands (Fig. 1) as proposed by Floeter et al. (2008) and used by Briggs \& Bowen (2012) on a review of Marine Zoogeographic Provinces.

\footnotetext{
Acknowledgments

We are grateful to S.M. Lima, A.V. Vasconcellos and N.N. Dias for the suggestions during manuscript preparation, C. Polaz and F. Di Dario for suggestions and helpful comments on IUCN criteria, and R. M. Dias for kindly taken photographs. Financial support was provided by Conselho Nacional de Desenvolvimento Científico e Tecnológico (CNPq) doctoral fellowship, and Coordenação de Aperfeiçoamento de Pessoal de Nível Superior (CAPES) for postdoctoral fellowship grant number 2346/2011 (PNPDinstitucional) to DFA. GSA was funded by CNPq. MRB was funded by Fundação Carlos Chagas Filho de Amparo à Pesquisa do Estado do Rio de Janeiro (FAPERJ; E-111.268/ 2014) and CNPq.
} 


\section{Authors' contributions}

Conceived and designed the experiments: DFA GSA. Performed the experiments: DFA GSA MRB. Analyzed the data: DFA GSA MRB CLSS. Contributed materials/analysis tools: DFA GSA MRB CLSS. Wrote the paper: DFA GSA MRB CLSS. All authors have read and approved the final manuscript.

\section{Competing interests}

The authors declare that they have no competing interests.

\section{Author details}

'Departamento de Vertebrados, Universidade Federal do Rio de Janeiro/ Museu Nacional, Setor de Ictiologia, Quinta da Boa Vista s/n, CEP 20940-040 Rio de Janeiro, RJ, Brazil. ${ }^{2}$ Universidade Federal de Alagoas, Campus Arapiraca, Unidade de Ensino Penedo, Av. Beira Rio s/n, CEP 57200-000 Penedo, AL, Brazil

Received: 26 April 2016 Accepted: 6 June 2016

Published online: 20 July 2016

\section{References}

Absalão RS. Padrões distributivos e zoogeografia dos moluscos da plataforma continental brasileira. Parte III. Comissão oceanográfica Espírito Santo I. Rio de Janeiro. Mem Inst Oswaldo Cruz. 1989;84(4):1-6. doi:10.1590/S007402761989000800006

Almeida DF. Filogeografia e sistemática de Elacatinus figaro Sazima, Moura \& Rosa, 1997 (Perciformes: Gobiidae) no Atlântico oeste tropical, PhD thesis. Rio de Janeiro, Brazil: Universidade Federal do Rio de Janeiro; 2011.

Bemvenuti MA. Diferenciação geográfica do peixe-rei Odontesthes argentinensis (Atherinopsidae), no extremo sul do Brasil, através da morfometria multivariada. Atlantica. 2000;22:71-9. doi:10.1590/S0101-81752002000100024.

Boschi EE. Species of decapod crustaceans and their distribution in the American marine zoogeographic provinces. Revista de Investigacion y Desarrollo Pesquero. 2000;13:7-64

Briggs JC. Marine zoogeography. NewYork: McGraw-Hill; 1974

Briggs JC. Global biogeography. Amsterdam: Elsevier; 1995.

Briggs JC, Bowen BW. A realignment of marine biogeographic provinces with particular reference to fish distributions. J Biogeogr. 2012;39:12-30. doi:10. 1111/j.1365-2699.2011.02613.x.

Castro CB, Pires DO. Brazilian coral reefs: What we already know and what is still missing. Bull Mar Sci. 2001;69:357-71.

Colin PL. Larvae retention: Genes or oceanography? Science. 2003;300:1657-9. doi:10.1126/science.300.5626.1657c

Colin PL. Fishes as living tracers of connectivity in the tropical western North Atlantic: I. Distribution of the neon gobies, genus Elacatinus (Pisces: Gobiidae). Zootaxa. 2010;2370:36-52.

Di Dario F, Petry AC, Mincarone MM, Pereira MMS, dos Santos RM. New records of coastal fishes in the northern Rio de Janeiro State, Brazil, with comments on the biogeography of the south-western Atlantic Ocean. J Fish Biol. 2011; 79:546-55. doi:10.1111/j.1095-8649.2011.03035.x.

Ekman S. Zoogeography of the sea. London: Sidgwick and Jackson; 1953.

Eschmeyer, W. N., R. Fricke, and R. van der Laan (eds). Catalog of fishes: Genera, Species, References. (2016) (http://researcharchive.calacademy.org/research/ ichthyology/catalog/fishcatmain.asp). Electronic version accessed 18 April 2016.

Floeter SR, Rocha LA, Robertson DR, Joyeaux JC, Smith-Vaniz WF, Edwards AJ, Barreiros JP, Ferreira CEL, Gasparini JL, Brito A, Falcón JM, Bowen BW Bernardi G. Atlantic reef fish biogeography and evolution. J Biogeogr. 2008:35:22-47. doi:10.1111/j.1365-2699.2007.01790.x.

Gasparini JL, Floeter SR, Ferreira CEL, Sazima I. Marine ornamental trade in Brazil. Biodivers Conserv. 2005:14:2883-99. doi:10.1007/s10531-004-0222-1.

Giokas S, Sfenthourakis S. An improved method for the identification of areas of endemism using species co-occurrences. J Biogeogr. 2008;35:893-902. doi:10. 1111/j.1365-2699.2007.01840.x

ICMBio. (2015) Peixes - Elacatinus figaro Sazima, Moura \& Rosa, 1996 - Neon. http://www.icmbio.gov.br/portal/biodiversidade/fauna-brasileira/lista-deespecies/6257-especie-6257.html (Acessed: 16 Apr 2015)

IUCN Standards and Petitions Subcommittee. Guidelines for Using the IUCN Red List Categories and Criteria. Version 9.0. Prepared by the Standards and Petitions Subcommittee. 2011 Accessible at http://www.iucnredlist.org/ documents/RedListGuidelines.pdf. Captured on 04 May 2014.

Linder HP. On areas of endemism, with an example from the African Restionaceae. Syst Biol. 2001;50:892-912.
Menni RC, Jaureguizar AJ, Stehmann MFW, Lucifora LO. Marine biodiversity at the community level: zoogeography of sharks, skates, rays and chimaeras in the southwestern Atlantic. Biodivers Conserv. 2010;19:775-96. doi:10.1007/ s10531-009-9734-z

Ministério do Meio Ambiente. Portaria MMA no. 444 - Reconhecer como espécies da fauna brasileira ameaçadas de extinção aquelas constantes da "Lista Nacional Oficial de Espécies da Fauna Ameaçadas de Extinção". (2014) Diário Oficial da União, seção 1, Brasília, DF

Morrone J. On the identification of areas of endemism. Syst Biol. 1994:43:438-41.

Moura RL, Sazima I, Rosa RS. Elacatinus figaro. In: Machado ABM, Drummond GM, Paglia AP, editors. Livro Vermelho da Fauna Brasileira Ameaçada de Extinção, vol. II. Ministério do Meio Ambiente: Brasilia; 2008. p. 188-9.

Müller $P$. The dispersal centers of terrestrial vertebrates in the Neotropical realm: A study in the evolution of the Neotropical biota and its native landscapes. Hague: Biogeographica; 1973

Palumbi SR, Warner RR. Why Gobies are like hobbits. Science. 2003;299:51-2. doi:10.1126/science.1080775.

Pezold F. Evidence for a monophyletic Gobiinae. Copeia. 1993;3:634-43.

Rocha LA, Rosa IL. Baseline assessment of reef fish assemblages of Parcel Manel Luiz Marine State Park, Maranhão, north-east Brazil. J Fish Biol. 2001:58:985-98. doi:10.1111/j.1095-8649.2001.tb00549.x.

Rondinini C, Wilson KA, Boitani L, Grantham H, Possingham HP. Tradeoffs of different types of species occurrence data for use in systematic conservation planning. Ecol Lett. 2006;9:1136-45. doi:10.1111/j.1461-0248.2006.00970.x

Sazima I, Krajewski JP, Bonaldo RM, Sazima C. Octopus cleaned by two fish species at Fernando de Noronha Archipelago, SW Atlantic. Coral Reefs. 2004;22(4):484. doi:10.1007/s00338-004-0407-9.

Sazima I, Sazima C, Francini-Filho RB, Moura RL. Daily cleaning activity and diversity of clients of the barber goby, Elacatinus figaro, on rocky reefs in southeastern Brazil. Environ Biol Fish. 2000;59:69-77. doi:10.1023/A:1007655819374.

Sazima I, Moura RL, Rosa RS. Elacatinus figaro sp. n. (Perciformes: Gobiidae), a new cleaner goby from the coast of Brazil. Aqua J Ichthyol Aquat Biol. 1997:2(3):33-8

Sazima I, Moura RL. The shark Carcharhinus perezi cleaned by the goby Elacatinus randalli at Fernando de Noronha Archipelago, western South Atlantic. Copeia. 2000;2000(1):297-9.

Taylor MS, Hellberg ME. Marine radiations at small geographic scales: speciation in neotropical reef gobies (Elacatinus). Evolution. 2005;59(2):374-85.

Tyre AJ, Possingham HP, Lindenmayer DB. Inferring process from pattern: can territory occupancy provide information about life history parameters? Ecol Appl. 2001;11:1722-37 (http://www.jstor.org/stable/3061091).

Van Tassell JL. Gobiiformes of the Americas. In: Van Tassel JL, Kovačić M, Kapoor BG, editors. Patzner R.A. The Biology of Gobies. Enfield: CRC Press, Taylor and Francis Group, Science Publishers; 2011. p. 139-76.

Vermeij GJ. Biogeography and adaptation. Cambridge: Harvard University Press; 1978.

Warner RR, Palumbi SR. Response to: genetic evidence for local retention of pelagic larvae in a Caribbean reef fish. Science. 2003;300:1658. doi:10.1126/ science.300.5626.1657c

\section{Submit your next manuscript to BioMed Central and we will help you at every step:}

- We accept pre-submission inquiries

- Our selector tool helps you to find the most relevant journal

- We provide round the clock customer support

- Convenient online submission

- Thorough peer review

- Inclusion in PubMed and all major indexing services

- Maximum visibility for your research

Submit your manuscript at www.biomedcentral.com/submit
) Biomed Central 